\title{
RODZAJE CYBERZAGROŻEŃ I PRAWNE SPOSOBY IM PRZECIWDZIALANIA W KONTEKŚCIE STOSOWANIA CYFROWYCH PLATFORM TECHNOLOGICZNYCH W POLSCE I UE
}

DOI: $10.33141 /$ po.2021.3.05

\section{Krzysztof Bartczak Milena Bodych-Biernacka}

\section{Wprowadzenie}

$I_{\mathrm{n} e}^{\mathrm{n}}$ ntensywny rozwój technologiczny powoduje, że na rynek wprowadzanych jest coraz więcej innowacyjnych rozwiązań i systemów. Za takie uznać należy digital technology platforms, czyli cyfrowe platformy technologiczne (CPT), które stopniowo zastępują klasyczne innowacje produktowe (Ciriello i in., 2018, s. 563) i obecnie są jednym z najważniejszych trendów technologicznych (Nowicka, 2017, s. 45). Mogą one funkcjonować jako platformy: zakupowe (Aleo - Deloitte, 2015), usługowe (Twardowski, 2009), IT (Sun i in., 2015, s. 1), telewizyjne (Myślak, 2017, s. 31-55) czy nawet biblioteczne (Odlanicka-Poczobutt i in., 2015, s. 11-19), jak również, biorąc pod uwagę klasyfikację firmy konsultingowej Oxera, platformy informacyjne, komunikacyjne, rozrywkowe, porównawcze (służą do porównywania cen) i rynki online (Oxera, 2015, s. 3) oraz, według propozycji A. Kosieradzkiej i K. Rostek (2015, s. 462), platformy analityczno-komunikacyjne (wspomagają podejmowanie decyzji), integrująco-informacyjne (analiza danych i informacji) i służące do realizacji zadań związanych z wykorzystywaniem wiedzy. CPT to narzędzia, które prowadzą do intensyfikacji kontaktów handlowych i biznesowych nawiązywanych pomiędzy różnymi podmiotami działającymi na rynkach (w tym głównie między partnerami biznesowymi, stąd inne określenie
Przegląd Organizacji, Nr 3(974), 2021, s. 39-45

www.przegladorganizacji.pl

๑) Towarzystwo Naukowe Organizacji i Kierownictwa (TNOiK)
CPT - platformy B2B, czyli business-to-business) (Sun i in., 2015, s. 1-2). W innej definicji wskazano, że CPT to bazy kodów, które w każdym momencie można rozszerzać o nowe moduły i funkcjonalności (De Reuter i in., 2015, s. 5). Z kolei autorskie ujęcie brzmi: CPT to narzędzia o charakterze elektronicznym (cyfrowym), które mogą przyjmować postać usług bądź treści i za pośrednictwem których możliwe jest tworzenie podstaw do nawiązywania i intensyfikowania kontaktów pomiędzy różnymi podmiotami działającymi na rynku, przy czym bardzo ważną cechą tych platform jest możliwość stałego ich rozbudowywania o nowe moduły czy funkcjonalności.

Nowoczesne rozwiązania technologiczne, takie jak CPT, są niezwykle przydatne, jednak generują szerokie wyzwania, odnoszące się do cyberbezpieczeństwa (Spremić, Simunić, 2018, s. 341; Albrycht i in., 2019, s. 31). W tym względzie chodzi nie tylko o różnego typu ataki na komputery i sieci internetowe, ale również awarie sprzętu i oprogramowania, które mogą wynikać z błędów ludzkich (Kremer i in., 2019, s. 42). Z uwagi na to aktualnie podejmowane są działania w sferze prawnej, które mają na celu neutralizować zagrożenia związane z bezpieczeństwem nowoczesnych technologii i systemów IT, w tym także CPT. 
W artykule sformułowano następujące pytania badawcze:

- w jaki sposób, na gruncie prawnym, regulowane są kwestie dotyczące cyberbezpieczeństwa w odniesieniu do funkcjonowania cyfrowych platform technologicznych (cel poznaczy)?

- jakie podstawowe zagrożenia są związane z wykorzystywaniem cyfrowych platform technologicznych (cel poznawczy)?

- w jaki sposób przedmiotowe kwestie mogą wpływać na zarządzanie CPT, w szczególności, jak można przeciwdziałać powstającemu zagrożeniu przy ich wykorzystaniu (cel praktyczny)?

Głównym celem artykułu jest wskazanie, jakie zagrożenia dotyczą wykorzystywania CPT w przedsiębiorstwach i czy czas wykorzystywania tych platform w przedsiębiorstwach oraz wielkość zatrudnienia mają wpływ na skalę tych zagrożeń. Rozważania w tym zakresie zostaną osadzone w kontekście badań własnych.

\section{Przegląd literatury przedmiotu i ustawodawstwa}

$\mathbf{Z}$ uwagi na intensywny rozwój technologiczny, aktualnie istnieje duża potrzeba $\mathrm{w}$ odniesieniu do regulowania kwestii prawnych związanych z cyberbezpieczeństwem (Górka, 2018, s. 31). Bezpieczeństwo w cyberprzestrzeni jest definiowane jako brak ryzyka w odniesieniu do możliwości utraty danych informacyjnych, które to dane stanowią podstawowy czynnik wytwórczy, umożliwiający osiąganie przewagi konkurencyjnej na rynku (Aleksandrowicz, 2016, s. 12-13). Zapewnienie tego bezpieczeństwa jest podstawowym zadaniem nie tylko na poziomie funkcjonowania poszczególnych przedsiębiorstw, ale również ma wymiar krajowy czy, szerzej, międzynarodowy. W związku z tym cyberbezpieczeństwo musi stanowić istotny element polityki realizowanej na szczeblu państwowym czy unijnym (Terlikowski, 2019, s. 77). Przy tym powinna ona uwzględniać również funkcjonowanie CPT, gdyż grupują one wielu użytkowników i prowadzą do realizowania różnego typu transakcji, co może wywoływać zagrożenia, odnoszące się na przykład do utraty danych, wynikającej z ich kradzieży czy awarii sprzętu lub oprogramowania (Górka, 2017, s. 76; Opara, Hussein, 2017, s. 138).

W dyrektywie Parlamentu Europejskiego i Rady (UE) 2016/1148 z dnia 6 lipca 2016 r. w sprawie środków na rzecz wysokiego wspólnego poziomu bezpieczeństwa sieci i systemów informatycznych na terytorium Unii zaznaczono, że CPT, definiowane w tej dyrektywie w kontekście „internetowych platform handlowych”, czyli usług cyfrowych, które zapewniają zawieranie online umów dotyczących sprzedaży produktów, usług lub oprogramowania (art. 4 pkt 17 dyrektywy 2016/1148; Biesiekierska, 2019, s. 15), są przedmiotem działania dostawców usług cyfrowych. Tacy dostawcy, na mocy odpowiednich wymogów regulacyjnych i dobrowolnych praktyk branżowych, są zobowiązani do rozwijania kultury zarządzania ryzykiem, która dotyczy przeprowadzania ocen ryzyka i wdrażania środków bezpieczeństwa adekwatnych dla danego rodzaju ryzyka. Jest to istotne $\mathrm{z}$ tego powodu, że prawidłowe funkcjonowanie internetowych platform stwarza podstawy do zapewnienia bezpieczeństwa, ciągłości i wiarygodności realizacji usług cyfrowych, co tym samym wpływa na sprawną działalność prowadzoną przez przedsiębiorstwa oraz na „kluczową działalność gospodarczą i społeczną w Unii" (pkt. 44 i 48 preambuły dyrektywy 2016/1148).

W dyrektywie, wśród wymagań, jakie są stawiane państwom członkowskim w związku z koniecznością zapewnienia bezpieczeństwa usług cyfrowych, uwzględniono formułowanie krajowych strategii odnośnie do tego bezpieczeństwa, dzięki którym możliwe jest osiągnięcie i utrzymanie wysokiego jego poziomu. Poza tym ustalono, że dostawcy usług cyfrowych muszą podejmować odpowiednie i proporcjonalne środki o charakterze technicznym i organizacyjnym, pozwalające na zarządzanie ryzykiem i zapewnienie ciąłłości działania systemów i sieci informatycznych, w tym CPT, a także zgłaszać wszelkie incydenty do CSIRT (Zespołu Reagowania na Incydenty Bezpieczeństwa Komputerowego) i realizować zadania z zakresu monitorowania, audytu i testowania stanu systemów i sieci komputerowych (art. 7 i art. 14-16 dyrektywy 2016/1148).

Uzupełnieniem do tej dyrektywy jest rozporządzenie wykonawcze Komisji (UE) 2018/151 z dnia 30 stycznia 2018 r. W jego ramach wyodrębniono konkretne zabezpieczenia, jakie muszą być stosowane przez dostawców usług cyfrowych. Opisano je w tabeli 1 . Wyodrębnione $\mathrm{w}$ tabeli rodzaje zabezpieczeń to minimalne wymagania, jakie są stawiane sieciom i systemom informatycznym, w tym także CPT, w odniesieniu do cyberbezpieczeństwa.

W Polsce najważniejszym aktem prawnym, który reguluje kwestie dotyczące bezpieczeństwa CPT, jest ustawa z dnia 5 lipca 2018 r. o krajowym systemie cyberbezpieczeństwa. W jej ramach platformy te zaliczono do usług cyfrowych. Zgodnie z ustawą z dnia 18 lipca 2002 r. o świadczeniu usług drogą elektroniczną, usługi takie są świadczone na odległość, bez obecności stron, co odbywa się w wyniku przekazu danych realizowanego na indywidualne żądanie usługobiorcy za pomocą urządzeń, służących do elektronicznego przetwarzania i przechowywania danych (art. 2 pkt 4 ustawy z dnia 18 lipca 2002 r.). Wśród podstawowych obowiązków dostawców usług cyfrowych, czyli również tych podmiotów, które odpowiadają za bezpieczne funkcjonowanie CPT, znajduje się zapewnienie realizacji adekwatnych środków, pozwalających na sprawne postępowanie w przypadku incydentu, naruszającego cyberbezpieczeństwo, zarządzanie ciągłością działania oraz zapobieganie i minimalizowanie wpływu incydentów na usługi cyfrowe (art. 17 ust. 2-3 ustawy z dnia 5 lipca 2018 r.).

Należy dodać, że w dniu 22 października 2019 r. Rada Ministrów podjęła uchwałę w sprawie Strategii Cyberbezpieczeństwa Rzeczypospolitej Polskiej na lata 2019-2024. Jednym z głównych celów tej Strategii jest „podniesienie poziomu odporności systemów informacyjnych administracji publicznej i sektora prywatnego oraz osiągnięcie zdolności do skutecznego zapobiegania i reagowania na 
Tabela 1. Zabezpieczenia stosowane przez dostawców usług cyfrowych na mocy rozporządzenia wykonawczego 2018/151

\begin{tabular}{|c|c|}
\hline Obszar zabezpieczeń & Rodzaje zabezpieczeń \\
\hline \multirow{4}{*}{$\begin{array}{l}\text { Bezpieczeństwo sieci i systemów } \\
\text { informatycznych }\end{array}$} & $\begin{array}{l}\text { - systematyczne zarządzania sieciami i systemami informatycznymi, w tym mapowanie, analiza } \\
\text { ryzyka i architektury bezpieczeństwa oraz zarządzanie cyklem życia systemów }\end{array}$ \\
\hline & $\begin{array}{l}\text { - bezpieczeństwo fizyczne i środowiskowe - dostępność zestawu środków, które pozwalają na } \\
\text { eliminację błędów ludzkich czy awarii systemów }\end{array}$ \\
\hline & $\begin{array}{l}\text { - bezpieczeństwo dostaw - realizacja odpowiednich polityk w celu zagwarantowania } \\
\text { i identyfikowania dostaw }\end{array}$ \\
\hline & - kontrolowanie dostępu do systemów \\
\hline \multirow{4}{*}{ Postępowanie w przypadku incydentu } & - testowanie odpowiednich procesów \\
\hline & - identyfikowanie słabych punktów systemów \\
\hline & - ocenianie powagi incydentów \\
\hline & - dokumentowanie wyników podjętych środków \\
\hline \multirow{2}{*}{ Zarządzanie ciągłością działania } & - stosowanie planów awaryjnych \\
\hline & - wykazywanie zdolności do przywracania gotowości do pracy sieci i systemów po katastrofach \\
\hline \multirow{3}{*}{ Monitorowanie, audyt i testowanie } & - realizacja zaplanowanej sekwencji obserwacji i pomiarów \\
\hline & - weryfikowanie wykorzystywania odpowiednich norm i wytycznych \\
\hline & - ujawnianie luk w bezpieczeństwie sieci i systemów \\
\hline
\end{tabular}

Źródło: opracowanie wtasne na podstawie art. 2 rozporządzenia wykonawczego 2018/151

incydenty", co ma być osiągane w wyniku przeprowadzania testów i audytów bezpieczeństwa oraz zapewnienia bezpieczeństwa w ramach łańcuchów dostaw systemów i sieci informatycznych (Strategia ..., 2019, s. 15-16).

W ustawie z dnia 18 lipca 2002 r. o świadczeniu usług drogą elektroniczną również zawarto szereg wymagań, jakie muszą być spełnione przez dostawcę usług cyfrowych. W kontekście cyberbezpieczeństwa chodzi głównie o zapewnienie przez tego dostawcę działania systemu teleinformatycznego w taki sposób, by nie było możliwe uzyskanie dostępu przez nieuprawnione osoby do treści przekazów, jakie składają się na te usługi (art. 7 ust. 1 pkt ustawy z dnia 18 lipca 2002 r.).

W trakcie funkcjonowania CPT niezbędne jest również uwzględnianie przepisów dotyczących ochrony danych osobowych (Chałubińska-Jentkiewicz, 2018, s. 187-191). W tym względzie należy powołać się na RODO - rozporządzenie Parlamentu Europejskiego i Rady (UE) 2016/679 z dnia 27 kwietnia 2016 r. w sprawie ochrony osób fizycznych w związku $\mathrm{z}$ przetwarzaniem danych osobowych i w sprawie swobodnego przepływu takich danych oraz uchylenia dyrektywy 95/46/WE, czyli rozporządzenie o ochronie danych osobowych. Nakłada ono na dostawców usług cyfrowych obowiązki między innymi w zakresie zgodnego $\mathrm{z}$ prawem i bezpiecznego przetwarzania danych osobowych, co dotyczy każdorazowego wyrażenia zgody na takie przetwarzanie przez zainteresowaną stronę oraz ochrony, za pomocą odpowiednich środków technicznych lub organizacyjnych, przed niedozwolonym lub niezgodnym z prawem przetwarzaniem oraz przypadkową utratą, zniszczeniem lub uszkodzeniem danych (chodzi o integralność i poufność danych) (art. 5-6 RODO). Należy dodać, że w Polsce, na podstawie przepisów zawartych w RODO, funkcjonuje ustawa z dnia 10 maja 2018 r. o ochronie danych osobowych.

Regulacje prawne w stosunkowo szeroki sposób odnoszą się do kwestii związanych z zapewnianiem bezpieczeństwa działania cyfrowych platform technologicznych. Jest to istotne $\mathrm{z}$ tego względu, że wykorzystywanie CPT wiąże się z określonymi zagrożeniami, co może implikować bariery w ich wykorzystywaniu. Będzie o tym mowa przy omawianiu wyników badań własnych.

\section{Metoda badawcza}

B adania zostały przeprowadzone w dniach 18-28 lutego 2019 r. metodą standaryzowanych wywiadów kwestionariuszowych, czyli zawierających pytania o ściśle określonej kolejności i niezmiennym brzmieniu, na ogół zamknięte. W tym zakresie wykorzystano metodę CATI (Computer-Assisted Telephone Interviewing), a więc wywiady telefoniczne wspomagane komputerowo. Podstawą ich realizacji był kwestionariusz ankiety, składający się z 23 pytań. Metoda CATI odznacza się wysokim stopniem standaryzacji i jest elementem paradygmatu ilościowego, przy czym do jej podstawowych zalet zalicza się to, że jej wyniki można uogólnić na całą populację (Gerring, 2001, s. 15).

Próba miała charakter losowy. Wywiady zostały zrealizowane z przedstawicielami kadry zarządzającej, posiadającymi wiedzę z zakresu funkcjonowania i wykorzystywania przez przedsiębiorstwa cyfrowych platform technologicznych. Operat losowania stanowiły listy 
beneficjentów Programu Operacyjnego Innowacyjna Gospodarka realizowanego przez Polską Agencję Rozwoju Przedsiębiorczości. Do próby wylosowano przedsiębiorstwa, które otrzymały w ramach tego programu dofinansowanie na wdrożenie i rozwój cyfrowych platform technologicznych. Operat losowania liczył N=320 rekordów, z czego wywiady udało się zrealizować z liczbą podmiotów $\mathrm{N}=120$. Algorytm randomizacji wbudowany w oprogramowanie do badań telefonicznych zapewnił każdemu rekordowi w bazie danych jednakową szansę znalezienia się $\mathrm{w}$ próbie. W toku realizacji badania nawiązano kontakt telefoniczny $\mathrm{z}$ każdym $\mathrm{z}$ przedsiębiorstw. W badaniach uczestniczyły przedsiębiorstwa, których długość działania na rynku to głównie 85 miesięcy i dłużej (81,0\% ogółu) i które funkcjonują przede wszystkim w ramach średnich $(33,9 \%)$ oraz dużych $(32,2 \%)$ przedsiębiorstw. Wśród branż, w których prowadzona jest działalność przedsiębiorstw, znajduje się głównie branża handlowa $(23,1 \%)$, informatyczna $(21,5 \%)$ oraz przemysłowa $(20,7 \%)$.

W trakcie analizy uzyskanych danych wykonano również porównania międzygrupowe, opierając się na teście rangowym $\mathrm{H}$ Kruskala-Wallisa, nazywanym potocznie nieparametryczną analizą wariancji, oraz teście U Manna-Whitneya. Pierwsze z narzędzi statystycznych zostało wprowadzone do obiegu naukowego w połowie XX w. przez Kruskala i Wallisa (1952, s. 583-621). Test ten umożliwia stwierdzenie, czy w dużej $(\mathrm{k}>2)$, wieloelementowej grupie istnieją istotne statystycznie różnice pomiędzy elementami. Jeśli ten test wykaże takie różnice, wówczas wykorzystuje się kolejny, czyli test Manna i Whitneya (1947, s. 50-60) w celu porównania parami elementów składających się na grupę. W trakcie badań, przy wykorzystaniu obu testów, chodziło o odnalezienie swoistych „cech charakterystycznych” wykorzystania CPT z perspektywy różnych grup badanych (wielopłaszczyznowa charakterystyka badanej populacji).
Założenia i kierunki eksploracji wyznaczone zostały przez pytania, które przyjęto jako zmienne niezależne. Dotyczyły one czasu stosowania cyfrowych platform technologicznych $\mathrm{w}$ badanych przedsiębiorstwach oraz wielkości zatrudnienia.

\section{Wyniki badań}

W trakcie badań z zakresu cyfrowych platform technologicznych (część poświęcona cyberbezpieczeństwu) respondentów spytano między innymi o to, jakie zagrożenia można dostrzec w związku z wdrażaniem CPT w badanych przedsiębiorstwach w obszarze cyberbezpieczeństwa. Analiza deklaracji ankietowanych w tym względzie została zawarta w tabeli 2, przy czym należy zaznaczyć, że osoby badane mogły wskazać dowolną liczbę odpowiedzi.

Według respondentów badań, do najważniejszych zagrożeń, jakie są związane $\mathrm{z}$ wykorzystywaniem CPT $\mathrm{w}$ przedsiębiorstwach, zalicza się awarie sprzętu komputerowego (65 wskazań, czyli 36,1\% ogółu) i sieci internetowej (43 wskazań i 23,9\% ogółu). W znacznie mniejszym stopniu ankietowani wskazali na phishing $(6,7 \%)$ i pharming $(5,05 \%)$ czy wycieki danych, dotyczących przedsiębiorstwa, kontrahentów bądź klientów (razem 10,0\%). Należy dodać, że 1,7\% członków populacji badawczej, a więc 2 osoby wykazały negatywny stosunek względem wdrażania i wykorzystywania CPT. Wprawdzie nie jest to duży odsetek, jednak warto zwrócić uwagę na to, że obie te osoby, wśród przejawów takiego negatywnego stosunku, wskazały na liczne obawy w zakresie cyberbezpieczeństwa.

W ramach porównań międzygrupowych pod uwagę wzięto kwestię, dotyczącą negatywnych zdarzeń i zagrożeń w związku z wdrażaniem CPT w kontekście cyberbezpieczeństwa. Analiza odnośnie do tej kwestii $\mathrm{w}$ powiązaniu $\mathrm{z}$ czasem stosowania CPT $\mathrm{w}$ badanych przedsiębiorstwach została zawarta w tabeli 3 .

Tabela 2. Zagrożenia z zakresu cyberbezpieczeństwa związane z wdrażaniem CPT

\begin{tabular}{|c|c|c|}
\hline \multirow{2}{*}{ Rodzaje zagrożeń } & \multicolumn{2}{|c|}{ Odpowiedzi } \\
\hline & $N=120$ & $\%$ \\
\hline awaria sprzętu komputerowego & 65 & 36,1 \\
\hline $\begin{array}{l}\text { awaria sieci internetowej, wynikająca na przykład z jej przeciążenia wykorzystywaniem cyfrowych } \\
\text { platform technologicznych }\end{array}$ & 43 & 23,9 \\
\hline phishing, czyli podszywanie się pod zaufane źródło poprzez stronę internetową & 12 & 6,7 \\
\hline pharming, czyli przekierowanie na fałszywą stronę i serwery internetowe & 10 & 5,6 \\
\hline wyciek danych dotyczących przedsiębiorstwa i jego pracowników czy kontrahentów & 6 & 3,3 \\
\hline wyciek danych dotyczących klientów & 6 & 3,3 \\
\hline utrata środków finansowych & 6 & 3,3 \\
\hline szpiegowanie poprzez sieć internetową & 3 & 1,7 \\
\hline negatywne zdarzenia nie wystąpiły & 28 & 15,6 \\
\hline Ogółem & 180 & 100,0 \\
\hline
\end{tabular}

Źródło: opracowanie wtasne 
Tabela 3. Zagrożenia dla cyberbezpieczeństwa w kontekście czasu stosowania CPT

\begin{tabular}{|c|c|c|c|c|}
\hline \multirow{3}{*}{ Rodzaje zagrożeń } & \multicolumn{4}{|c|}{ Czas stosowania CPT w przedsiębiorstwie } \\
\hline & \multicolumn{2}{|c|}{ do 3 lat } & \multicolumn{2}{|c|}{ powyżej 3 lat } \\
\hline & $N=120$ & $\%$ & $N=120$ & $\%$ \\
\hline awaria sprzętu komputerowego & 30 & 51,7 & 35 & 56,5 \\
\hline awaria sieci internetowej & 19 & 32,8 & 24 & 38,7 \\
\hline wyciek danych dotyczących przedsiębiorstwa i jego pracowników czy kontrahentów & 4 & 6,9 & 1 & 1,6 \\
\hline wyciek danych dotyczących klientów & 4 & 6,9 & 1 & 1,6 \\
\hline phishing & 5 & 8,6 & 7 & 11,3 \\
\hline pharming & 3 & 5,2 & 7 & 11,3 \\
\hline utrata środków finansowych & 4 & 6,9 & 1 & 1,6 \\
\hline szpiegowanie poprzez sieć internetową & 2 & 3,4 & 1 & 1,6 \\
\hline negatywne zdarzenia nie wystąpiły & 13 & 22,4 & 15 & 24,2 \\
\hline Testy porównań międzygrupowych H Kruskala-Wallisa i U Manna-Whitneya & \multicolumn{4}{|c|}{$\begin{array}{c}\text { nieistotny statystycznie (w przypadku wszystkich rodzajów } \\
\text { zagrożeń) }\end{array}$} \\
\hline
\end{tabular}

Źródło: opracowanie własne

Tabela 4. Zagrożenia cyberbezpieczeństwa w zależności od wielkości przedsiębiorstwa $(\mathrm{N}=120)$

\begin{tabular}{|c|c|c|c|c|c|c|c|c|}
\hline \multirow{3}{*}{ Rodzaje zagrożeń } & \multicolumn{8}{|c|}{ Wielkość przedsiębiorstwa } \\
\hline & \multicolumn{2}{|c|}{ mikro } & \multicolumn{2}{|c|}{ małe } & \multicolumn{2}{|c|}{ średnie } & \multicolumn{2}{|c|}{ duże } \\
\hline & $\mathbf{N}$ & $\%$ & $\mathbf{N}$ & $\%$ & $\mathbf{N}$ & $\%$ & $\mathbf{N}$ & $\%$ \\
\hline awaria sprzętu komputerowego & 3 & 25,0 & 11 & 39,3 & 23 & 56,1 & 28 & 71,8 \\
\hline awaria sieci internetowej & 4 & 33,3 & 9 & 32,1 & 20 & 48,8 & 10 & 25,6 \\
\hline $\begin{array}{l}\text { wyciek danych dotyczących przedsiębiorstwa i jego } \\
\text { pracowników czy kontrahentów }\end{array}$ & 0 & 0,0 & 2 & 7,1 & 1 & 2,4 & 2 & 5,1 \\
\hline wyciek danych dotyczących klientów & 0 & 0,0 & 0 & 0,0 & 4 & 9,8 & 1 & 2,6 \\
\hline phishing & 3 & 25,0 & 1 & 3,6 & 3 & 7,3 & 5 & 12,8 \\
\hline pharming & 2 & 16,7 & 2 & 7,1 & 3 & 7,3 & 3 & 7,7 \\
\hline utrata środków finansowych & 0 & 0,0 & 2 & 7,1 & 1 & 2,4 & 2 & 5,1 \\
\hline szpiegowanie poprzez sieć internetową & 0 & 0,0 & 1 & 3,6 & 1 & 2,4 & 1 & 2,6 \\
\hline negatywne zdarzenia nie wystąpiły & 7 & 58,3 & 9 & 32,1 & 6 & 14,6 & 6 & 15,4 \\
\hline \multirow{5}{*}{$\begin{array}{l}\text { Testy porównań międzygrupowych H Kruskala- } \\
\text { Wallisa i U Manna-Whitneya }\end{array}$} & \multicolumn{5}{|c|}{ awaria sprzętu vs wielkość } & \multicolumn{3}{|c|}{$\mathrm{H}\left(\chi^{2}(3, \mathrm{~N}=120)=11,46 ; \mathrm{p} \leq 0,05\right.$} \\
\hline & \multicolumn{5}{|c|}{ mikro vs średnie } & \multicolumn{3}{|c|}{$\mathrm{U}(\mathrm{N}=54)=178,5 ; \mathrm{p} \leq 0,05$} \\
\hline & \multicolumn{5}{|c|}{ mikro vs duże } & \multicolumn{3}{|c|}{$\mathrm{U}(\mathrm{N}=52)=130,0 ; \mathrm{p} \leq 0,05$} \\
\hline & \multicolumn{5}{|c|}{ małe vs duże } & \multicolumn{3}{|c|}{$\mathrm{U}(\mathrm{N}=67)=368,5 ; \mathrm{p} \leq 0,05$} \\
\hline & \multicolumn{5}{|c|}{ w przypadku pozostałych zmiennych } & \multicolumn{3}{|c|}{ nieistotny statystycznie } \\
\hline
\end{tabular}

Źródło: opracowanie wtasne

Obie badane grupy przedsiębiorstw nie różnią się w istotny sposób pod względem wystąpienia negatywnych zdarzeń i zagrożeń wynikających z wykorzystania CPT. W przypadku zarówno przedsiębiorstw wykorzystujących platformy do trzech lat, jak i tych o dłuższym stażu wskazano, że do najczęstszych zdarzeń należą awarie sprzętu komputerowego (w ponad połowie badanych przedsiębiorstw) oraz awarie sieci internetowej.

Test porównań międzygrupowych wykonano również w odniesieniu do skali cyberzagrożeń w zależności od wielkości przedsiębiorstwa. Dane w tym zakresie przedstawiono w tabeli 4 . 
Rozkłady częstości wystąpienia poszczególnych zagrożeń i negatywnych zdarzeń związanych z użytkowaniem CPT są podobne dla każdej z badanych firm. Przedsiębiorstwa różnią się istotnie statystycznie jedynie pod względem występowania awarii sprzętu komputerowego. Tego typu zdarzenia liczniej pojawiają się w przypadku przedsiębiorstw średnich $(56,1 \%)$ i dużych $(71,6 \%)$. Istnieje również związek między występowaniem awarii a wielkością przedsiębiorstwa. Wraz ze wzrostem liczby zatrudnionych zwiększają się przypadki wystąpienia awarii sieci komputerowych.

Dzięki uzyskanym wynikom badań możliwe stało się wskazanie wszystkim podmiotom, które zajmują się kwestiami dotyczącymi zarządzania przedsiębiorstwami, tego, $\mathrm{z}$ jakimi rodzajami cyberzagrożeń mogą się spotkać w ramach wykorzystywania cyfrowych platform technologicznych oraz w jaki sposób, biorąc pod uwagę uregulowania prawne, można się przed takimi zagrożeniami skutecznie zabezpieczyć. Wyniki badań mogą więc stworzyć warunki do efektywniejszego niż dotychczas funkcjonowania przedsiębiorstw, czyli takiego, w którym wszelkie zagrożenia $\mathrm{z}$ zakresu cyberbezpieczeństwa, wynikające $\mathrm{z}$ użytkowania CPT, będą bardzo szybko neutralizowane.

\section{Podsumowanie}

C yberbezpieczeństwo to niewątpliwie jeden z najważniejszych problemów, jaki wiąże się z funkcjonowaniem cyfrowych platform technologicznych. Świadczy o tym fakt regulowania kwestii prawnych odnoszących się do niego w aktach normatywnych unijnych i krajowych. Chodzi między innymi o dyrektywę 2016/1148 i rozporządzenie wykonawcze 2018/151, a także ustawy o krajowym systemie cyberbezpieczeństwa i o świadczeniu usług drogą elektroniczną. W unormowaniach tych przewidziano szczególne wymagania, jakie są stawiane dostawcom usług cyfrowych w kontekście cyberbezpieczeństwa. Chodzi między innymi o zapewnienie odpowiednich procedur, pozwalających na szybkie reagowanie na wszelkie incydenty $\mathrm{w}$ zakresie cyberbezpieczeństwa, analizowanie ryzyka, testowanie najbardziej adekwatnych procedur, ochronę danych osobowych czy stałe monitorowanie i przeprowadzanie audytów bezpieczeństwa. Istnienie przepisów w tym zakresie, co potwierdzają badania własne, jest konieczne. Wynika to $\mathrm{z}$ tego, że $\mathrm{w}$ dużej części badanych przedsiębiorstw dochodzi do różnego rodzaju incydentów związanych z cyberbezpieczeństwem. Najszerszą skalę mają one w przypadku awarii komputerów czy sieci internetowej, choć zdarzają się również ataki typu phishing i pharming czy wycieki danych. Zagrożenia takie mogą stanowić istotne bariery wdrażania CPT w przedsiębiorstwach. Dlatego prawne normowanie kwestii dotyczących stosowanych przez dostawców usług cyfrowych konkretnych zabezpieczeń jest pożądane i niezwykle potrzebne. Należy zauważyć także, że na podstawie testu porównań międzygrupowych Kruskala-Wallisa i Manna-Whitneya istnieje związek między występowaniem awarii a wielkością przedsiębiorstwa, a wraz ze wzrostem liczby zatrudnionych, zwiększają się przypadki wystąpienia awarii sieci komputerowych.

\author{
mgr inż. Krzysztof Bartczak \\ Politechnika Warszawska \\ Wydział Zarządzania \\ ORCID: 0000-0001-7406-1509 \\ e-mail: krzysztof.bartczak@pw.edu.pl
}

\section{Bibliografia}

[1] Albrycht I., Autolitano S., Gęborys P., Krawczyk M., Marczuk P., Mednis A., Siudak R., Świątkowska J. (2019), Wyzwania w cyberprzestrzeni, Instytut Kościuszki, Sopot.

[2] Aleksandrowicz T.R. (2016), Bezpieczeństwo w cyberprzestrzeni ze stanowiska prawa międzynarodowego, „Przegląd Bezpieczeństwa Wewnętrznego”, Nr 8, s. 11-28.

[3] Aleo - Deloitte (2017), Digitalizacja rynku B2B. Cyfrowe platformy zakupowe - raport Aleo i Deloitte, https:// www2.deloitte.com/content/dam/Deloitte/pl/Documents/Reports/pl_Raport_Aleo_Deloitte_2016_ONLINE_01.pdf, data dostępu: 25.11.2020 r.

[4] Biesiekierska A. (2019), Ustawa o krajowym systemie cyberbezpieczeństwa. Komentarz, Wydawnictwo C.H. Beck, Warszawa.

[5] Chałubińska-Jentkiewicz K. (2019), Bezpieczeństwo prawne danych osobowych $w$ nowych warunkach cyfrowych, „Zeszyty Naukowe KUL”, Nr 1, s. 179-196.

[6] Ciriello R.F., Richter A., Schwabe G. (2018), Digital Innovation, „Business \& Information Systems Engineering", Vol. 60, No. 6, pp. 563-569.

[7] De Reuver M., Sørensen C., Basole R.C. (2015), The Digital Platforms: A Research Agenda, „Journal of Information Technology", No. 4, pp. 124-135.

[8] Dyrektywa Parlamentu Europejskiego i Rady (UE) 2016/1148 z dnia 6 lipca 2016 r. w sprawie środków na rzecz wysokiego wspólnego poziomu bezpieczeństwa sieci i systemów informatycznych na terytorium Unii, Dz.Urz. UE L 194 z 19.07.2016 r.

[9] Gerring J. (2001), Social Science Methodology: A Criterial Framework, Cambridge University Press, Cambridge.

[10] Górka M. (2018), Cyberbezpieczeństwo jako wyzwanie dla wspótczesnego państwa i spoteczeństwa, [w:] T. Dębowski (red.), Cyberbezpieczeństwo wyzwaniem XXI wie$k u$, Wydawnictwo Naukowe Archaegraph, Łodź - Wroclaw, s. 31-50.

[11] Górka M. (2017), Technologia informacyjna w obszarze cyberbezpieczeństwa państwa i społeczeństwa, „Systemy Wspomagania w Inżynierii Produkcji”, Nr 5, s. 73-89. 
[12] Kosieradzka A., Rostek K. (2015), Koncepcja platformy komunikacyjno-ustugowej dla struktur sieciowych, [w:] R. Knosala (red.), XVIII Konferencja Innowacje w zarządzaniu i inżynierii. Materialy konferencyjne. Tom 1, Polskie Towarzystwo Zarządzania Produkcją, Zakopane 2015, s. 458-469.

[13] Kremer S., Ludovic M., Rémy M., Roca V. (eds.), (2019), Cybersecurity. Current Challenges and Inria's Research Directions. Rocquencourt (France): The National Institute for Research in Computer Science and Automation, Rocquencourt.

[14] Kruskal W.H., Wallis W.A. (1952), Use of Ranks in One-Criterion Variance Analysis, „Journal of the American Statistical Association”, Vol. 47, No. 260, pp. 583-621.

[15] Mann H.B., Whitney D.R. (1947), On a Test of Whether one of Two Random Variables is Stochastically Larger than the Other, „The Annals of Mathematical Statistics”, Vol. 1, No. 18, pp. 50-60.

[16] Myślak D.A. (2017), Telewizja cyfrowa i jej cyfrowe pochodne a oczekiwania wspótczesnego odbiorcy, „Media, Kultura, Komunikacja Społeczna”, Nr 1, s. 31-55.

[17] Nowicka K. (2017), Rozwój świata wirtualnego i jego wplyw na e-mobilność, [w:] J. Gajewski, W. Paprocki, J. Pieriegud (red.), E-mobilność. Wizje i scenariusze rozwoju, Centrum Myśli Strategicznych, Sopot, s. 40-61.

[18] Odlanicka-Poczobutt M., Olko S., Kramnich M. (2015), Cyfrowe platformy biblioteczne jako instrument zarzqdzania wiedza w organizacji, [w:] M. Odlanicka-Poczobutt (red.), Systemy biblioteczne nowej generacji. Platformy ustug, Gliwice, 15-16 października 2015 r., TYPO Usługi Wydawnicze, Gliwice, s. 11-19.

[19] Opara E.U., Hussein M.T. (2017), Cyber Security, Threat Intelligence: Defending the Digital Platform, „Journal of International Technology and Information Management", Vol. 26, No. 1, pp. 138-160.

[20] Oxera (2015), Benefits of online Platforms, https:// www.oxera.com/getmedia/84df70f3-8fe0-4ad1-b4ba-d235ee50cb30/The-benefits-of-online-platforms-main-findings-(October-2015).pdf.aspx?ext=.pdf, access date: 25.11.2020.

[21] Rozporządzenie Parlamentu Europejskiego i Rady (UE) 2016/679 z dnia 27 kwietnia 2016 r. w sprawie ochrony osób fizycznych w związku z przetwarzaniem danych osobowych i w sprawie swobodnego przepływu takich danych oraz uchylenia dyrektywy 95/46/WE, Dz.Urz. UE L 119 z 4.05.2016 r.

[22] Rozporządzenie wykonawcze Komisji (UE) 2018/151 z dnia 30 stycznia 2018 r. ustanawiające zasady stosowania dyrektywy Parlamentu Europejskiego i Rady (UE) 2016/1148 w odniesieniu do dalszego doprecyzowania elementów, jakie mają być uwzględnione przez dostawców usług cyfrowych w zakresie zarządzania istniejącymi ryzykami dla bezpieczeństwa sieci i systemów informatycznych, oraz parametrów służących do określenia, czy incydent ma istotny wpływ, Dz.Urz. UE L 126 z 31.01.2018 r.

[23] Spremić M., Simunić A. (2018), Cyber Security Challenges in Digital Economy, „Proceedings of The World Congress of Engineering", No. 1, pp. 341-346.
[24] Sun R., Keating B., Gregor S. (2015), Information Technology Platforms: Definition and Research Directions, [in:] F. Burstein, H. Scheepers, G. Deegan (eds.), Proceedings of the $26^{\text {th }}$ Australasian Conference on Information Systems (ACIS), Australasian Association for Information Systems, Adelaide, pp. 1-17.

[25] Terlikowski T. (2019), Bezpieczeństwo cyberprzestrzeni wyzwaniem naszych czasów. System cyberbezpieczeństwa $w$ Polsce (w świetle obowiązującego prawa), „Zeszyty Naukowe SGSP", Nr 3, s. 75-98.

[26] Twardowski B., SaaS: Zmieniamy podejście z lokalnych rozwiązań na platformy ustugowe, https://www.erp-view.pl/it_solutions/saas_zmieniamy_podejscie_z_lokalnych_rozwiazan_na_platformy_uslugowe.html, data dostępu: 25.11.2020 r.

[27] Uchwała Nr 125 Rady Ministrów z dnia 22 października 2019 r. w sprawie Strategii Cyberbezpieczeństwa Rzeczypospolitej Polskiej na lata 2019-2024, M.P. 2019 r., poz. 1037.

[28] Ustawa z dnia 18 lipca 2002 r. o świadczeniu usług drogą elektroniczną, Dz.U. 2002 r., Nr 144, poz. 1204 z późn. $\mathrm{zm}$.

[29] Ustawa z dnia 10 maja 2018 r. o ochronie danych osobowych, Dz.U. 2018 r., poz. 1000 z późn. zm.

[30] Ustawa z dnia 5 lipca 2018 r. o krajowym systemie cyberbezpieczeństwa, Dz.U. 2018 r., poz. 1560 z późn. zm.

\section{Types of Cyber Threats and Legal Methods of Counteracting Them in the Context of Using Digital Technology Platforms in Poland and the EU}

\section{Summary}

The aim of the publication is to characterise the risks related to the use of digital technology platforms, i.e. tools used to enter into transactions for the purchase and sale of specific products or services. Until now, the subject related to such threats has been taken up, but it has not been related to legal aspects at all - so the work has a significant contribution to the management and quality sciences or legal sciences. The study notes that the use of CPT in enterprises may generate specific threats, including those related to computer and Internet failure, specific attacks such as phishing and pharming, or data leakage. These threats may adversely affect the attitudes of company executives towards CPT and so inhibit the implementation of these platforms. To counter this problem, there are currently a number of legal regulations, that impose specific cybersecurity obligations on digital service providers. This includes, for example, analysing risk, identifying weaknesses in networks and IT systems, or conducting security audits.

\section{Keywords}

law, cybersecurity, digital technology platforms, personal data protection 